\title{
Innovating English Syllabus Design for Twenty-First Century Skills of $4 \mathrm{Cs}$
}

\author{
Elfi $^{1)}$, Hermawati Syarif ${ }^{2)}$ \\ ${ }^{1)}$ IAIN Batusangkar, ${ }^{2)}$ Universitas Negeri Padang \\ email: elfi@iainbayusangkar.ac.id ${ }^{1}, \underline{\text { hermawati_sy@yahoo.com }}^{2}$
}

\begin{abstract}
English syllabus design plays as an essential role in the language curriculum. It helps the teachers to make a plan for their teaching performance. The syllabus should describe many skills to be taught. In designing an English syllabus, the teachers not only describe English skills in the syllabus but also other skills. The skills to be accomplished in English teaching and learning nowadays is 4Cs $21^{\text {st }}$-century skills such as communication, collaboration, critical thinking, and creativity. English teachers are suggested to do some innovations in designing the English syllabus based on 4Cs skills in order to prepare the students to face 4.0 society and globalization era. Considering the importance of these skills, the purpose of this article is to describe some innovations of English syllabus design for 4Cs skills. A library research method is used to provide an overview of the integrating of these skills into the syllabus design, including challenges faced by teachers in designing the syllabus based on 4Cs skills as well as a set recommendation for English teachers in designing English syllabus for $21^{\text {st }}$ century of 4Cs. The article concludes with a discussion around the innovation of designing an English syllabus of 4Cs skills.
\end{abstract}

Keywords: Innovating, English syllabus design, Twenty-first Century Skills of 4Cs

\section{Introduction}

The process of curriculum development, implementation, and evaluation can be regarded as an important element of curriculum planning. The curriculum is a system of both decision-making and behavior related to curriculum functions for specific population groups. Therefore, the curriculum plan has three main functions. Creating an identifiable population curriculum, implementing the curriculum in a particular school, and assessing the effectiveness of the developed curriculum. Not only curriculum development leads to lesson planning that includes evaluation factors and the potential for school improvement, but an important unit of educational change is the individual school. The main decisionmakers for curriculum implementation are principals, teachers, students, parents, and communities. Therefore, a major part of education and learning is the location of the local school.

The curriculum develops over time as well as the development of education and society. If the curriculum changes, practitioners should pay attention to the effort to meet the needs of students, schools, and communities (Barton, Garvis \& Ryan, 2014). The curriculum changes were also affected by the social changes. Changes in the world economic situation, work requirements. Therefore, training requires the student to be prepared for this condition. It means that education is designed to prepare students for life in the 21 st century.

In the 21st century, English teachers should follow the development of the curriculum since they have to implement it in the real classroom. Syllabus design is one of the components in the curriculum. Robinson (2011) defines syllabus design as regarding units. It is also the sequence of performance. The syllabus can help the teachers to remember list of things for what they are going to do in their teaching 
performance. Thomslinson (2011) suggests some points to design the syllabus such as: novelty, variety, attractive presentations, appealing content and achievable challenge.

Teaching English in the twenty first century is more challenges for English teachers since the demand of English teaching have to appropriate with the skills that be obligated nowadays. The skill that has to fulfill by the English teachers is twenty first century skill that called 4Cs skills, they are: communication, collaboration, creativity, and critical thing thinking. These skills should be incorporated to English teaching, because of that, English teacher have to design the syllabus based on 4Cs skills in order to prepare the student to face twenty first century life as the effect of changing the world and to get it can be done by increasing the developing of technology in global workforce. The National Education Association (2015) shows that $80 \%$ of executive believe fusing the 4Cs would ensure that students are better prepared to enter the workforce. In addition, Educational Leadership in Oliver (2016) explains that students need twenty first century skills such as 4 Cs skills to be success today. Due to the educators should pay attention to these skills.

The first skill of 4Cs is Critical thinking. This skill investigates problems in new ways and links learning across subjects and disciplines. This allows students to acquire other skills, such as: Improved concentration, deeper analytical skills, and improved thinking processing. Critical thinking and problem solving are defines to reason effectively, the use of systems thinking, making decision and solving problems. The second skill is creativity. It defines as trying new approaches to get things done, innovation, and invention. Creativity also defines as thinking creatively, work creatively with others, and implementing innovation. The next skill is collaboration. Collaboration is cooperated together and harnessing talent to reach goals. It is the ability and motivation to work. Collaboration emphasizing the ability to work effectively or with diverse teams. This includes the flexibility of exercise and the willingness to help make the compromises needed to achieve a common goal. This ability is also responsible for collaboration and assesses the individual contributions of individual team members. (Babu, 2020)

There are many reasons why the syllabus needs to be developed. The first reason is the teacher need to do some innovation in designing the syllabus in order to address the student's needs. The teacher can do need analyses of their students in learning the English subject. Based on the analysis, they can design the syllabus. The second reason is to actualize the institutional goals and objective. All institutions have different goals and objective. Before designing the syllabus, the teacher has to know about the goal and objective of the institution where they teach. They have to describe in the syllabus the objective of the instructions from the objective of study program. The following reasons are to develop content standards and graduate competence standards (SCLs) in the existing teaching and learning processes of relevant institutions.

Considering the essential of 4Cs skills in teaching English, some question arise to this point. Do English teachers design the syllabus based on 4Cs skills, how to design it? And what problems faced by teacher to integrate it in learning teaching process. Talking about the issues the teacher still gets problems to design the syllabus. Adam (2016) founds in his research that there were five main issues that English teachers encountered when designing an English syllabus. There were teaching material, classroom activity, media, timing, and textbook / source problems. Related to 4Cs skill, Lailil (2019) found that the teachers got the problem understanding the syllabus 4Cs.Some of them confused breakdown the syllabus to be indicators since every teacher have different understanding toward the syllabus. These questions and problems should be answered in order to ensure the integration of 4Cs skill in syllabus design. The purpose of this paper is to describe some innovations to design English syllabus based on 4Cs skills.

\section{Methods}

The writer used a library research method. The writer reviews journals, books, reports, company websites, and scholarly articles, and other academic publications related to innovation of English syllabus 
design based on 4Cs skills. The writer overviews some theories, and research reports related to English syllabus design of 4Cs skill to find out how to design the syllabus based on 4Cs skills.

\section{Results and Discussion \\ Innovating English Syllabus Design for Twenty-First Century Skills of 4Cs \\ a. $21^{\text {st }}$ century standard of 4Cs skills to design syllabus}

The Pacific Policy Research Center (2010) states that the partnership mentions six elements of 21st century skills to advance the 21 st century in the learning process. These six elements, highlighted in the core subject, emphasized the use of learning skills and evaluation tools in the 21 century and the centuries that followed. Based on the six elements used to build the 21st skill, the curriculum used at school corresponds to the aspect of the 21st skill by Alismail and McGuire (2015). Approved Ginanjar and Suhadi (2018) need Indonesia's national education standards to apply 21st century CCSS knowledge, that integrates the 21st century educational framework. By integrating these skills into curriculum design, students can gain a deeper understanding of the subject and try to solve real-life problems.

According to the P21 website, there are five standards for 21 st century features. The first Standard Focus will focus on 21 st century skills, content, and expertise. The second criterion is, which facilitates understanding between major 21 st century subjects and interdisciplinary topics. The third criterion is, which emphasizes deeper understanding than superficial knowledge. The next criterion is to connect students to real-world data, tools, and professionals they find at school, at work, and in life. The final standard allows for several control measures.

The above criteria will help teachers design their syllabus. These criteria should be included in the curriculum. Paige (2009) suggests that the 21st Curriculum needs to combine Knowledge, Thinking, Innovation, Media, Information and Communication Technology (ICT) in the context of the core subject of scholarship. In addition, Lombardy (2007) students will have the knowledge and life skills they need to succeed in their future careers. Curriculum developers of the curriculum specified on P21 should be designed to enable students to acquire knowledge and understand scientific and disciplinary core knowledge. In addition, this curriculum should provide students with the opportunity to learn and develop a variety of skills such as citizenship, finance, the environment, health and global awareness.

There are many factors that influence the design of the curriculum. According to Tagg and Woodward (2011), factors are trends in command practices, theories of second language pedagogy, broader educational contexts, course objectives, and learner backgrounds. When designing a curriculum, the general design takes shape and determines how to design small lesson blocks. The educational block must be self-contained, but it still contributes to the overall purpose of the curriculum (Richards, 2001).

\section{b. How to design the syllabus of 4Cs skills}

Curriculum design is the selection and organization of instructional content, including proposed strategies for content presentation and evaluation (Brown, 1995), and a series of planned steps leading to narrower defined goals at each level. (Sundayana, 2006).

The curriculum includes competencies. It is synonymous with ability or high-level skill, well knowledge, or elaborate performance (Hadley, 2001). A competency-based curriculum is similar to a competency-based curriculum in language education. It defines what the learner can do with respect to a particular skill as a result of the lesson. It refers to the observable behavior required to successfully complete an activity in the real world (Richard, 2001). Competency units can be tasks, roles, functions, or learning modules. Competency elements can be defined as any characteristic of a person who contributes to successful completion of tasks, work, function, academic and work environment activities. Curriculum components consist of competency-based curriculum, classroom content, learning experience, and goals or competencies in assessment. When designing a curriculum based on $4 \mathrm{C}$ skills, teachers need to write the competence based on $4 \mathrm{C}$ skills. 
To design of English syllabus, The first thing that teachers have to do is developing syllabus based on need analysis. They can conduct to do need analysis, work with a group of teachers in collaboration with relevant institutional needs analysts/experts and program directors of institution. The information could be collected about resources, objective, method of assessment, and need analysis should be an ongoing process throughout the course. Related to 4Cs skill analysis, the teachers have to nalize students need analysis toward 4Cs skill. The teacher should find out What are students need toward creative thinking, creative, communication and collaboration skills.

Furthermore, Teachers can develop the curriculum using an analytical and holistic approach. An analytical curriculum born from a communicative approach. It's about the learning process, not the content. It is the actual process that facilitates inter-language development. An approach to curriculum design in Wilkin's terminology cited in Allwright (1997). This is an approximation of the learner's own language behavior, and the entire language has not been analyzed "(p. twenty-two). Nunan (1988) defines the analytical curriculum as a curriculum that presents the target language at once across blocks, without language interference or control. Or (b) Learner exposure to natural samples from L2. The procedure, process, and task curriculum are an example of analytical-type curriculum. The synthetic approach is defined as the design of the curriculum as the various parts of the language are separated and gradually taught. From this approach, the acquisition is the process of gradually accumulating parts until the entire structure of the language is built. This approach emphasizes that the linguistic elements taught are grammatical structures and the arrangement of lists of vocabulary elements.

\section{c. Steps in Developing Syllabus Based on $4 C$ skills}

Technically, according to Sundayana (2006), syllabus design steps include planning, implementation, evaluation, and revision. The first step is the planning and specification phase. Teachers can do the following stage: (a) Identify existing content standards, graduate competence standards, and a wealth of resources and textbooks based on 4C skills, (b) Use information gathered through a needs analysis of student background knowledge and expectations based on 4C skills, (c) Identify the competencies specified in the content standards (Competency Standards and Basic Competencies) and the Graduate Competency Standards (SKL), (d) Formulate the basic abilities of the core material based on the 4C skills, (e) Use learning task analysis to analyze core materials and identify grammatical elements and textual and conceptual meanings, taking into account the three learning areas proposed in education. Objectives Support skills include cognitive, intellectual skills, psychomotor and emotional areas, language, culture, discourse skills, and previous student knowledge and skills. Core materials need to be suitable for 4C skills that help students develop critical thinking, creative, communication, and collaboration skills, (f) Determine the evaluation tool by taking into account the indicators formulated based on the 4Cs skills, (g) Decide the timing by considering indicators, range of materials, student prior knowledge, level and so on, and (h) decide which learning sources to use.

The second stage in developing English syllabus for 4Cs skills is dissemination and implementation stage. There are many steps that can do by teachers, including: (a) Develop the test such as pretest, formative test and achievement test. The test than should be developed should be tested of students 4Cs skills, (b) Develop teaching materials. Teaching material should be appropriate with 4Cs skills, (c) Socialize the syllabus and its components based on 4Cs skills, and (d) Do ongoing evaluation for the implementation of $4 \mathrm{Cs}$ skills. The evaluation and revision is the last stage. The teacher can do an evaluation with a team or related experts including related English subject matter teachers. The result of the evaluation is used to reconstruct the syllabus.

\section{d. Designing Syllabus of 4Cs skills into KKNI Syllabus}

Sumiati (2015) stated technology development can change the curriculum. The 21st century education is education that integrates knowledge, skills, and attitudes, information and communication technology mastery. The 4Cs skills are demanded in this century as same as the demanded of KKNI 
curriculum. Designing syllabus of $\mathrm{KKN}$ has been explained by SN Diktis related to the procedure, principle, element, and assessment. Based on SN Dikti (2018), there are many principles of KKNI syllabus or RPS design. First, RPS or other terms are learning program documents designed to produce graduates who have the ability according to the CPL that has been determined, so that it must be carried out by students at every stage of learning in related subjects. Second, RPS or other terms are focused on how to guide students to learn in order to have the ability in accordance with the CPL of graduates who charged to the course, not the interests of the lecturer's activities teach. Then, the learning designed in the RPS is centered on learning to students (Student-Centered Learning abbreviated as SCL). Finally, RPS or other terms must be periodically reviewed and adjusted according to the development of science and technology.

Based on those principles, the stages of designing RPS based on KKNI curriculum are: (a) identify the CPL that is decided for the course, (b) formulate specific course learning outcomes (CPMK) to the courses based on the CPL that is designed, (c) formulate sub CPMK which is the final capability that is planned at each learning stage, and it is formulated based CPMK, (d) do learning analysis to provide an overview of students learning stage that will be undertaken, (e) determine indicators of achievement of sub-CPMK as the final capability that planed at each stage of learning to meet the CPL, (f) establish assessment criteria and develop assessment instruments learning based on indicators of achievement of sub-CPMK, (g) select and develop learning forms, learning methods, and students' assignments as a learning experience, (h) develop learning materials in the form of appropriate teaching materials and learning resources, and (i) develop and evaluate learning. Evaluation learning consists of first, formative evaluation which aims to make an improvement in the learning process, summative evaluation which aims to determine students' learning outcomes.

RPS, according to SN-Dikti, contains the name of the study program, the name and code of the course, semester, credits, the name of the lecturer. It supports the learning outcomes of graduates charged to the courses. The final capabilities are planned at each stage of learning to meet the learning outcomes of graduates. Then, the materials are related to the capabilities to be achieved which will be presented through appropriate learning methods. It also contains the time allotted to achieve the ability at each stage. Students' learning experiences are embodied in the job description must be done by students for one semester. After that, the criteria, indicators, and assessment weights should be clear. Finally, the list of references used should be stated.

In general, the assessment technique can be seen from four aspects of assessment, namely: attitudes, general skills, specific skills, and knowledge. The lecturer can design students' performance results rubric. A rubric is a guide or assessment guide that describes desired criteria in assessing or grading results student learning performance. The rubric consists of the dimensions or aspects that are assessed and criteria for student learning outcomes or achievement indicators of student in learning.

The next is designing portfolio assessment. Portfolio assessment is an ongoing assessment based on a collection of information that shows the development of learning achievement students in a certain period. The information can be in the form of works students from the learning process that is considered the best or work. Students who demonstrate the development of their ability to achieve learning outcomes. The types of portfolios that can be arranged are a development portfolio, containing a collection of student works, to show progress in achieving their abilities in accordance with the stages learned what has been done. A showcase portfolio containing works. Students who show their best learning performance results. Portfolio comprehensively containing the results of students' work during the learning process.

Moreover, the lecturer has to design an assessment mechanism. The assessment mechanism is related to the assessment stages, assessment techniques, assessment instruments, assessment criteria, assessment indicators, and assessment weights. Then, the lecturers asked to do an assessment procedure that includes many stages such as a) Planning (can be done through a phased assessment and/or 
assessment repeat), b) activities of giving assignments or questions) performance observation, d) return of observation results and final rating.

The last one is the implementation of assessment. The assessment is carried out in accordance with the learning plan and can be carried out by a team of supporting lecturers, a teaching lecturer team by including students, and/or the teaching lecturer team by including relevant stakeholders.

\section{Innovation 4Cs skills in English Syllabus of KKNI Curriculum}

English teachers can do some innovation to design the syllabus for 4Cs skill by incorporating these skills into four English skill such as listening, speaking, reading and writing. Jhon Stocks in Dennis (2017) suggests teachers prepare students for new global society. According to AMA 2010, proficiency in listening, speaking, reading and writing is not sufficient if the employee is unable to think critically, solve problems, collaborate or communicate effectively. The first innovation that teachers should do is conceptualize the competency of English skill into the competency of 4Cs skill. The competence of 4Cs can be seen in the Table 1 below:

Table 1. 4Cs Competence

\begin{tabular}{|c|c|}
\hline Framework & Thinking Competence p21 \\
\hline $\begin{array}{l}\text { Creativity thinking and } \\
\text { innovation }\end{array}$ & $\begin{array}{l}\text { Students can independently create, develop, and } \\
\text { implement ideas in groups. }\end{array}$ \\
\hline $\begin{array}{l}\text { Critical thinking and } \\
\text { problem solving }\end{array}$ & $\begin{array}{l}\text { Students can identify, analyze, interpret, and } \\
\text { evaluate evidence, discussions, claims, and data } \\
\text { that are fully presented and reflected in daily life } \\
\text { through in-depth research. }\end{array}$ \\
\hline Communication & $\begin{array}{l}\text { Students can effectively communicate their ideas } \\
\text { using both oral and written media. }\end{array}$ \\
\hline Collaboration & $\begin{array}{l}\text { Students can work together in groups to solve } \\
\text { problems that they found. }\end{array}$ \\
\hline
\end{tabular}

Based on the competency above, the teacher conceptualizes the English competency for each skill and incorporate it into the competencies of 4Cs skills. The teacher can design the syllabus by planning a series of activities, organize the lesson and develop the material focus on 4Cs skills. Halvorsen (2018) explains that four languages skills can easily be activated when the teachers design the activities based on 4Cs skill in teaching English. The teacher can ask the students to research a topic discuss and ask them to debate the topic with pairs and write what they found. The teachers design the activities to teach the students how to communicate effectively in real life situation both verbally and in writing to understand the role of effective communication as global citizens. They also suggested to design the activities to teach the students how to cooperate with others friends and appreciate teamwork. Beside that they can design the activities to teach the students to be creative and innovative to find out different ways to tackle the problems, and not afraid of taking risk. Furthermore, they can design the syllabus to teach the students to be critical thinkers and problem solvers to sort out the overload of information available at their fingertips.

The 4Cs skills of communication, collaboration, critical thinking and creativity can be categorized into life skills that must be owned by anyone, especially students, to be able to compete in the workforce. It can illustrate in table 2 below:

Table 2. Learning and Innovation Skills

\begin{tabular}{lll}
\hline \multicolumn{1}{c}{ 21st Century Skills } & \multicolumn{3}{c}{ Description } \\
\hline Learning and & 1. & Think critically and solve problems: \\
innovation skill & Students can overcome problems in \\
& different situations using a variety of \\
\hline
\end{tabular}

Language Learning Innovation in Pandemic Covid-19 Era

https://proceeding-icolp.fbs.unp.ac.id 


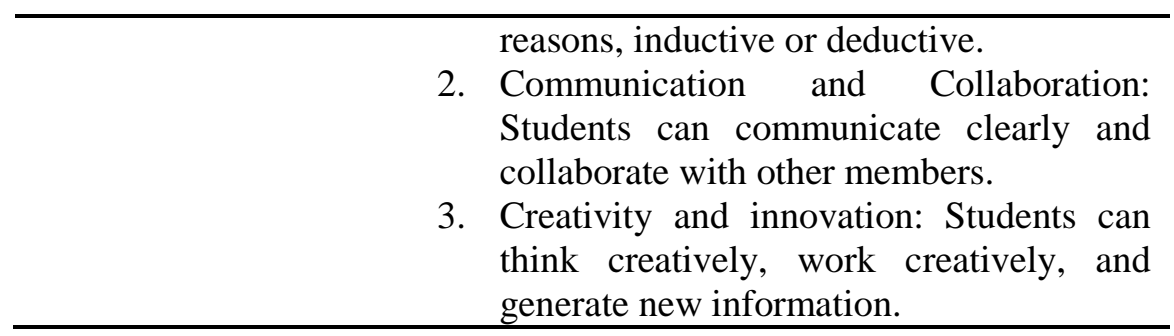

The description has been elaborated by Pacific Policy Research Centre (2010). The first skills are critical thinking skills. It is the ability to understand complex problems, combine information with other information, and finally come up with another perspective when solving the problem. Students had to have critical thinking skills in their daily lives. Students who can think critically can effectively solve problem, which is a social, academic, and practical problem. Knowledge and information alone are not enough to solve problems and make decisions. To be effective at work (and in personal life), students must be able to solve problems and make effective decisions. They must be able to think critically. Characteristics of critical thinking: a) Effectively discuss, b) Ask specific questions and solve problems, c) Analyze and evaluate alternative perspectives, d) Critically reflect in decision making, various Process the environment. In addition, Polo (2018) states that Critical thinking is through a determined attempt to collect relevant information, asking the important questions that help solve the problem, select appropriate criteria to make decisions, and identify alternatives to make credible decisions., Realized by students. Gathering relevant information was clear when the instructor asked the students what media they could use to teach a particular skill.

The relevant information gathering activity is ideal for stimulate students' inductive and deductive thinking when they are able to generalize information and draw conclusions. More over an important question was asked, which greatly contributed to finding a way to the given problem. It was achieved when the student confirmed whether to include all points or only one point in the instructor's assignment. Without such clarity in this regard, students would have a hard time carrying out the activity, but a clear focus relieved the difficulty. This skill was mainly used and activated in the classroom. It can be done by providing a variety of learning activities that required critical thinking. Some activities included not only critical thinking, but also three other skills. For example, when asked to teach one of four language skills, students study a particular skill and choose the appropriate educational media to justify their media choices. In this activity, they need to think critically and convey what they were thinking in order to be able to understand others. Without these two skills, it will be difficult to do any activity. It should also be noted that critical thinking was achieved through individual and group task. The ability of critical thinking enables efficient work on technical and logistics issues.

The second skill is communication. It refers to the skill of a person to communicate clearly in spoken, written, and non-verbal languages. There are many characteristics of communication skills such as: a) Effectively express thinking and ideas using oral, written, and non-verbal communication skills in various forms and contexts, b) Decoding the meaning of knowledge, values, attitudes, intentions, etc. Listen effectively to what you do, c) different purposes, d) know how to use multiple media and technologies to assess their effectiveness and influence them in advance, e) different environment.

The third skill is collaboration. It has become a trend in the 21 st century. There is a growing need to move from individual efforts to group work and from independence to community, to think about and collaborate on important social issues. Collaboration is the act of working together to achieve a common goal 21 The century is the ability to effectively collaborate with diverse teams to acquire collaboration skills. Collaboration is not only synonymous with student group work, but also aims to give students the ability to socialize and control their ego and emotions. Working together creates a sense of unity, personal responsibility, and care among the members. The characteristic of collaboration skills is: a) Demonstrate 
the ability to work effectively and the respect with diverse teams. b) Show the flexibility and willingness to make beneficial compromises to achieve common goals. c) Share responsibility for collaborative work and evaluate individual contributions.

The last skill is creativity. It is the ability of each team member of students to innovate creativity. Creativity is the ability to create new ideas from existing ideas. Creativity relies on creative thinking, a thinking process that creates new ideas that lead to new discoveries, and it is often referred as innovation. The characteristic of creativity and innovation skills are: a) Develop and apply new ideas, pass on new inventions to others, often referred to as innovation. b) Open and responsive when displaying new different views and c) Use technology to make decisions and solve problems.

The description of those skills above can help teachers to make the learning objective in the syllabus. Wilson at all (2000) suggest the teacher to design the syllabus by designing the learning outcome of the program and course learning outcome with 4Cs skills. To design the outcome of critical thinking skills, the teacher can describe in the syllabus clearly. There are descriptions of think critically by creating, integrate and evaluate idea across a range of context, culture and area of knowledge. For creativity skills can be described with recognizing and solve problems using creativity, analysis and intuition.

In addition, for communication skills, should be elaborated in learning outcome to communicate with clarity and originally. The teachers should describe the ability to exchange the ideas and information that is essential to personal growth, productive work and social vitality. It can be described clearly in the syllabus by organizing and articulating ideas for a range of audiences and purposes. The teachers can describe the use of technology to gather, process, and communicate information.

The lecturers can explain the method in the English syllabus and apply it to increase students' ability in English skills. The method should be appropriate with the objective of each English skills and 4Cs skill. They also have to teach using innovative technologies to make the students have good participation and increase their cognitive and social skills with good content knowledge. It can be done by applying approach-based learning as suggested by Joyce et all (2009) who says that problem-based learning increase increase students' participation in the classroom. It also improves students critical thinking (Triling and Fadel, 2009). In addition, Thomas (2007) suggests project-based learning that can be described in the curriculum and syllabus.

The teacher also suggested to use problem-based learning and describe it in the syllabus. DalingHanmont et all (2008) suggest the teacher to use problem based learning. It can be done by asking students to works in groups to research and pose solution to problems. It can create a collaborative and multifaceted environment.

Furthermore, the teacher can use design-based learning and describe it in the syllabus. Hmelo, Holton \& Kolodner (2000) explains that design-based learning activities support the students to design the project. It asks the student to work collaboratively. The teachers can describe the activities or topics that benefit to the students to work together and get some experience. The teacher can set the rules so that all of students have opportunity to participate. All of the active can be seen in the syllabus.

The syllabus also describes the assessment. To integrate 4Cs skill of 21 st century, the teachers have to designed the assessment of teaching English skill with the century assessments. The P21 assessment recommends the assessment systems based on multiple measures od students' abilities of century skills. It should be listed in integral part of the academic assessments. The assessment has to include incorporation of students in achieving 4Cs skills. According to Silvia (2009) the meaningful assessment of 21 st century, should be describe in the curriculum and syllabus. Critical thinking skill can be assisted by using multiple choice testing. While Gramer in Pacific policy research center (2010) suggests digital portfolio as the assessment of 4Cs skills. It had positive impact on students' achievement across the curriculum and syllabus. Cooperative learning also the pedagogy to enhance 21 st century skills. It is the strategy support the students to work more creative. It allows the students to contribute different degrees of prior knowledge, abilities and attitude. It also increases students' motivation. (Joice et al, 2009). 
In short, to design English syllabus the teacher or lecturer can integrate the 4Cs skill for all of component and do some innovation in the syllabus, start from the competence standard of program, course competence, instructional contents, teaching activities, method, strategy, students' task, learning experience and assessment or evaluation.

\section{Conclusion}

The syllabus changes always bring challenges to all education parties specially for the teachers. The change of syllabus happened base on the need of the students and the demand of society. This paper highlighting the innovation of 4Cs of 21 th century skills, they are: communication, collaboration, critical thinking and creativity. This article elaborates the design of English syllabus by making some innovation in order to improve the quality of teaching and produce 4Cs skills of students in facing the 21 th century life, 4.0 society, and globalization era. To make some innovation, the teachers have understood how to integrate this skill and implement it in their syllabus. The innovation can be done in planning, implementation, evaluation and revision stage of the English syllabus by incorporating it to 4Cs skills.

\section{References}

Allwright, R. L. (1997). Seminar notes from "Contributions to Language Learning I", M.A. E.L.T. Unit, Department of Applied Linguistics, and Lancaster University. October December.

Alismail, P \& McGuire. (2015). 21st century standards and curriculum: Current research and practice. Journal of Education and Practice, 6(6), 150-155.

Barton, G. M., Garvis, S., \& Ryan, M. E. (2014). Curriculum to the Classroom: Investigating the Spatial Practices of Curriculum Implementation in Queensland Schools and its Implications for Teacher Education. Australian Journal of Teacher Education, 39(3).

Chiruguru, S. (2020). The essensial skill of 21 st century classroom (4Cs). doi:10.13140/RG.2.2.36190. 59201.

Partnership for 21st Century Skills. (2009). Framework for $21^{\text {st }}$-century learning. Washington, DC: Author.

Polo, B. J., Silva. P. A. \& Crosby, M. E. (2018). Applying studio-based learning methodology in computer science education to improve 21st-century skills. In Zaphiris, P., \& Ioannou, A.(Eds.). Learning Collaboration and Technology 2018, LNCS 10925, pp. 361-375, Las Vegas: Springer International Publishing.

Paige, J. (2009). The 21st century skills movement. educational leadership, 67, 11.

Handayani, N. (2017). Becoming the effective English teachers in the 21st century: What should know and what should do? 1st English Language and Literature International Conference (ELLiC), 6 May, 2017, 156-164.

Hadley, A.O. (2001). Teaching language in context. Boston: Heinle \&. Heinle. 
Harjanti, M. H. (2018). The implementation of the 21th century competency for elementary school teachers at curriculum 2013 training central java province year 2017. Social Humanaties and Educational Studies (SHEs) Conference Series, 1(1), 523-531.

Lailil, Q. (2019). "Penerapan kurikulum berbasis pesantren dalam meningkatkan mutu lulusan di SMP Yayasan Pendidikan Islam Tarbiyatul Aulad (YAPITA) Surabaya." Undergraduate thesis, UIN Sunan Ampel Surabaya.

Lombardi, M. (2007). Authentic Learning for 21 st Century: An. Overview. Educause Learning Initiative, $1-12$.

Nunan D (1988). Syllabus design. Ney York: Oxford University Press.

Richards, J. C. (2001). Curriculum development in language teaching. Cambridge: Cambridge University Press.

Robinson, S. K. (2006). "Do schools kill creativity?" Presentation at TED2006 conference, Monterey, CA.

Silva, E. (2009). Measuring skills for 21st-century learning. Phi Delta Kappan, 90(9).

Tomlinson, B. (2011). Material development in Language Teaching (2nd Ed.). Cambridge: Cambridge University Press .

Trilling \& Fadel. (2009). 21st Century Learning Skills. San Francisco, CA: John Wiley \& Sons.

Wilson, C. D., et al. (2000). Learning outcomes for the 21 st century: Report of a community college study. League for Innovation in the Community College: The Pew Chartable Trust. 